\title{
The Dienes Phenomenon: Identification of the Determinants of Compatibility
}

\author{
By BERNARD W. SENIOR \\ Department of Bacteriology, University of Dundee, Dundee DDI $9 S Y$, Scotland
}

(Received I I March 1977; revised 3 June 1977)

\begin{abstract}
Two hundred and four isolates of swarming strains of Proteus species which had been typed for their ability to produce bacteriocin (proticine) and also their proticine sensitivity (P/S typing) were tested in all combinations for their Dienes compatibility with each other. Ninety-eight distinct Dienes compatibility groups were found. Physiological and genetic experiments supported the evidence of typing results that, irrespective of species, both the type of proticine a strain produces ( $P$ type) and the sensitivity of the strain to proticine ( $S$ type) were determinants of Dienes compatibility. Strains showing compatibility in the Dienes test were of the same $\mathrm{P} / \mathrm{S}$ type, whereas those of different $\mathrm{P} / \mathrm{S}$ types were incompatible.
\end{abstract}

\section{INTRODUCTION}

When different strains of Proteus species are allowed to swarm towards each other, a line of completely or partially inhibited growth appears where the haloes of spreading growth of incompatible strains meet. This phenomenon, observed by Dienes (1946), forms the basis of the Dienes test and, although the phenomenon has never been satisfactorily explained, it has been used successfully to determine the relationship between strains of Proteus species in studies of cross-infection (Story, 1954; Skirrow, 1969).

Cunliffe \& Krikler (1953) suggested that the chief determinant of compatibility in the Dienes test was the $\mathrm{H}$ antigen. This may not be universally true, for more recent reports indicate that serologically identical strains may be of different Dienes types (De Louvois, 1969) and strains with the same $\mathrm{O}$ antigen but different $\mathrm{H}$ antigens may be of the same Dienes type (Skirrow, 1969). Skirrow (1969) suggested that a bacteriocin may be involved but Sourek (1968) found no evidence for this.

The different types of bacteriocins (proticines) produced by many strains of Proteus species, the sensitivity of these strains to proticines and a new typing method based on two kinds of observation (production/sensitivity typing) have recently been described (Senior, 1977). This paper presents evidence that the determinants of the Dienes type of a strain involve both the type of proticine it produces ( $P$ type) and its sensitivity to proticines (S type).

\section{METHODS}

Bacterial strains. Two hundred and fifty strains of Proteus species, principally Proteus mirabilis, were isolated at random from samples of urine, faeces and pus received for routine bacteriological examination. Twenty-four Cradock-Watson $(\mathrm{CW})$ proticine indicator strains and $10 \mathrm{cW}$ standard proticine-producing strains were kindly donated by Mr T. L. Pitt, Cross-Infection Reference Laboratory, Colindale, London. All strains were maintained on nutrient agar slopes in screw-capped bottles at $4{ }^{\circ} \mathrm{C}$ in the dark. They had been tested for their ability to produce proticine active on the $\mathrm{cW}$ indicator strains and for their sensitivity to the proticines produced by the $\mathrm{Cw}$ proticine-producing strains. Each strain had also been tested against all the others as a potential proticine producer and potential proticine-sensitive strain. Three of the several new proticines which were discovered to have different action spectra from the $10 \mathrm{cw}$ producers were added to the latter to make a new standard set of 13 proticine-producing strains. Thirteen indicator strains were selected 

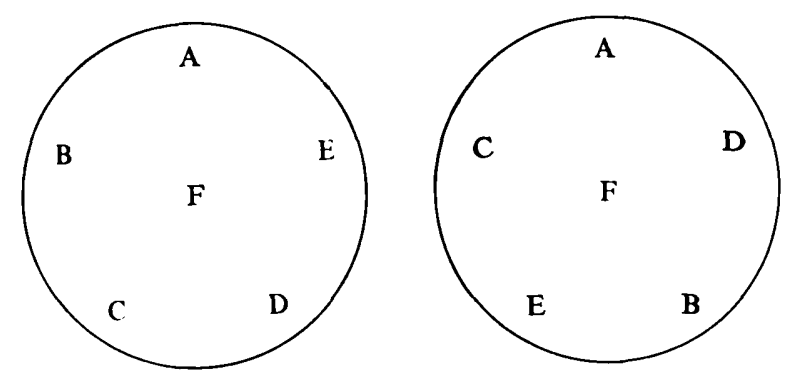

Fig. I. Position of inocula for testing the Dienes compatibility of six strains in all combinations.

which were sensitive to only one of these 13 newly defined standard proticine-producing strains and these were referred to as the standard indicator strains. The type of proticine a strain produced was referred to as its $\mathbf{P}$ type and the type of proticine to which it was sensitive, as its $\mathbf{S}$ type (Senior, 1977).

Proticine production and proticine sensitivity $(P / S)$ typing of strains. Though the $\mathrm{P} / \mathrm{S}$ type of each strain was originally determined on MacConkey agar (Oxoid CM7) (Senior, 1977), the strains were retyped on blood agar plates [Oxoid CM55 blood agar base and $5 \%(\mathrm{v} / \mathrm{v})$ horse blood] supplemented with either $\mathrm{I} \%(\mathrm{w} / \mathrm{v})$ sodium taurocholate or $0.2 \mathrm{mM}$-p-nitrophenylglycerol (Kopp, Müller \& Lemme, 1966) to prevent swarming. Loopfuls of $16 \mathrm{~h}$ tryptone water (Oxoid CM87) cultures of the 13 standard proticine-producing strains or strains whose $\mathbf{P}$ type was to be determined were streaked across the plates. After incubation at $37^{\circ} \mathrm{C}$ for I8 $\mathrm{h}$ the growth was removed and the plates were sterilized with chloroform. Loopfuls of tryptone water cultures of the standard set of indicators or strains whose $S$ type was to be determined, which had been incubated for $4 \mathrm{~h}$ at $37^{\circ} \mathrm{C}$, were streaked across the plates at right angles to the streaks of the producer strains. The plates were incubated for $18 \mathrm{~h}$ at $37^{\circ} \mathrm{C}$ and examined for areas of proticine-inhibited growth.

Proticine production under conditions permitting swarming. Two strains of different $\mathrm{P} / \mathrm{S}$ types were inoculated on to the opposite margins of a blood agar plate. After overnight incubation at $37^{\circ} \mathrm{C}$, the position of the Dienes line was marked on the base of the plate, the growth over a wide area where the Dienes line had formed was removed with a microscope slide covered in Sellotape and the plates were sterilized with chloroform. Loopfuls of $4 \mathrm{~h}$ tryptone water cultures of a set of non-swarming proticine indicator strains were streaked at right angles to and over the position of the Dienes line. After $18 \mathrm{~h}$ incubation at $37^{\circ} \mathrm{C}$ the plates were examined for growth of the indicator strains.

Proticine production and sensitivity at $42{ }^{\circ} \mathrm{C}$. Loopfuls of $16 \mathrm{~h}$ tryptone water cultures of each of the 13 standard proticine-producing strains were streaked across four blood agar plates containing $p$-nitrophenylglycerol. Three plates were incubated at $37^{\circ} \mathrm{C}$, the fourth at $42^{\circ} \mathrm{C}$. After $18 \mathrm{~h}$ incubation the growth on each plate was removed and the plates were sterilized with chloroform. One plate incubated at $37^{\circ} \mathrm{C}$ and that incubated at $42{ }^{\circ} \mathrm{C}$ were cross-streaked with loopfuls of tryptone water cultures of the 13 standard indicator strains grown at $37^{\circ} \mathrm{C}$ for $4 \mathrm{~h}$, and the plates were examined after a further $18 \mathrm{~h}$ incubation at $37^{\circ} \mathrm{C}$. The two remaining plates originally incubated at $37^{\circ} \mathrm{C}$ were cross-streaked with tryptone water cultures of the 13 standard indicator strains grown at $42{ }^{\circ} \mathrm{C}$ for $24 \mathrm{~h}$, and then one plate was incubated at $42{ }^{\circ} \mathrm{C}$, and the other at $37^{\circ} \mathrm{C}$. After $18 \mathrm{~h}$ incubation, the plates were examined.

Isolation of proticine-resistant mutants. Potential proticine-resistant mutants were occasionally observed as small colonies in an area where the growth of a proticine-sensitive strain had been inhibited by proticine. Such single, well-isolated colonies were picked with a straight wire into tryptone water, incubated for $4 \mathrm{~h}$ at $37^{\circ} \mathrm{C}$ and tested for resistance to proticine. Those found to be resistant were later shown to be true proticineresistant mutants of the indicator strain, and not 'proticine-immune' colonies of the producer strain which might have arisen through incomplete sterilization of the producer strain, because they were of a different Dienes type from the producer strain and failed to produce the type of proticine produced by that strain.

Dienes typing of strains. A loopful of a $4 \mathrm{~h}$ tryptone water culture of each strain under test was applied to the surface of two dry blood agar plates. Inocula were arranged so that Dienes compatibility of six strains could be tested simultaneously in all combinations on the minimum number (i.e. two) of plates (Fig. I). The plates were incubated at $37^{\circ} \mathrm{C}$ for $18 \mathrm{~h}$ and examined with reflected light for the presence of Dienes lines. Some slow-spreading strains required a longer period of incubation, or a thicker layer of medium, or a reduced concentration of agar $(0.75 \%$, w/v) before the plates could be 'read'. Some strains were non-spreading under all conditions and therefore untypable. Care was required in reading the plates, because a nonspreading strain was often overrun by a neighbouring strain. If this event is not recognized (observation of the origin of the contours of swarming growth assisted in its recognition), the test will be wrongly interpreted as indicating compatibility. 


\section{RESULTS}

The object of this study was to investigate whether or not the characteristics of proticine production ( $\mathrm{P}$ type) and proticine sensitivity (S type) were involved as determinants of compatibility in the Dienes test. George (1974) had shown that proticine production varied in activity spectrum and titre when strains were typed on different media. Thus for P/S typing a medium had to be selected which prevented strains from swarming and was as similar as possible to blood agar, on which the Dienes compatibility reactions of swarming strains was tested, in order that neither medium composition nor the swarming phenomenon would affect the $\mathrm{P} / \mathrm{S}$ type of a strain under swarming and non-swarming conditions.

\section{Proticine production and sensitivity under swarming and non-swarming conditions}

By increasing the concentration of agar in blood agar medium from 1.5 to $5 \%(\mathrm{w} / \mathrm{v})$ swarming could be prevented but proticine production could no longer be detected. The addition of $\mathrm{I} \%(\mathrm{w} / \mathrm{v})$ sodium taurocholate to blood agar caused lysis of the red blood cells, but swarming was prevented and P/S typing was both possible and satisfactory. The addition of p-nitrophenylglycerol (PNPG) to blood agar to a concentration of $0.2 \mathrm{~mm}$ had no lytic effect on the red blood cells, swarming was again prevented and P/S typing was both possible and satisfactory. The $\mathrm{P} / \mathrm{S}$ types of most of the strains were compared after typing on MacConkey agar, taurocholate blood agar and PNPG blood agar. For all strains tested, the types were the same on all three media, proticine production and sensitivity being as good as, if not better on the supplemented blood agars than on MacConkey agar. PNPG blood agar was preferred to taurocholate blood agar because it did not lyse the red blood cells and was selected as the medium for $\mathrm{P} / \mathrm{S}$ typing in this work. The $\mathrm{P} / \mathrm{S}$ types of many nonswarming strains as determined on blood agar and PNPG blood agar were compared and found to be identical. It is believed, therefore, that the P/S types of swarming strains determined on PNPG blood agar, where swarming is prevented, are identical to those of the same strains when swarming on blood agar.

Under swarming conditions, the only proticines detected were those expected from the $P$ type of the strains. Proticine covered the area of growth and swarm as far as, but not beyond the Dienes line. When swarms of non-producing strains with different proticine sensitivities (i.e. Po/S $x$ and $\mathrm{Po} / \mathrm{S} y$ ) were examined, there was no inhibition of any of the indicators either in the area of swarm or in the area of the Dienes line, indicating that no proticine was detectable which might conceivably have arisen genetically or through cell lysis at the Dienes line.

\section{Dienes typing}

Of the 250 Dundee strains, $24 \mathrm{CW}$ indicator strains and $10 \mathrm{cW}$ producer strains, 204 were found to swarm on blood agar and were subsequently tested in all combinations with one another for Dienes compatibility, a total of 41616 tests. The results of these tests have been analysed and for ease of interpretation are presented (Table 1 ) as a list of the 98 Dienes compatibility groups found and the $\mathrm{P} / \mathrm{S}$ types of the strains belonging to these groups.

All strains within a compatibility group were compatible with each member of that group and incompatible with any strain in any other compatibility group. All members of a compatibility group, with only four exceptions, possessed the same $\mathrm{P} / \mathrm{S}$ type and this was specific to the compatibility group. It appeared therefore that the $\mathrm{P} / \mathrm{S}$ type was associated with Dienes compatibility.

Proticine sensitivity (S type) as a determinant of the Dienes type. If the mutual inhibition between different strains of Proteus species observed in the Dienes test is solely the outcome of proticine action, then all strains which do not produce proticine (type $\mathrm{Po} / \mathrm{S} x$ ) should be compatible with one another. The results presented in Table I demonstrate that this is not so. Several distinct Dienes types were formed among the non-proticine producing strains. 
Table I. The P/S types of the 98 Dienes compatibility groups found among 204 strains of Proteus species

\begin{tabular}{|c|c|c|c|}
\hline $\begin{array}{l}\text { Dienes } \\
\text { compatibility } \\
\text { group no. }\end{array}$ & Type strain & $\begin{array}{l}\text { Other mutually } \\
\text { compatible strains }\end{array}$ & $\begin{array}{l}\text { P/S type(s) } \\
\text { of strains in } \\
\text { group* }\end{array}$ \\
\hline I & Cw794 & P6,H6,H7 & $0 / 1 ; 0 / 1,5 ; 0 / 5$ \\
\hline 2 & E2 & & \\
\hline 3 & CI & F4,CIO & $0 / 1,8$ \\
\hline 4 & Q4 & R4 & $0 / 1,3 b, 8,12,13$ \\
\hline 5 & 19 & & o/rabcde, 13 \\
\hline 6 & N3 & D2 2 & $0 / 1,8,13$ \\
\hline 7 & A5 & & $0 / 1,8,11,13$ \\
\hline 8 & CW52 & & $0 / 2,3,5$ \\
\hline 9 & CW712 & & $0 / 3$ \\
\hline 10 & Cw380 & $\mathrm{x} 8, \mathrm{~B} 8$ & $0 / 4$ \\
\hline II & T5 & & $0 / 4$ \\
\hline 12 & Q6 & & $0 / 4,5$ \\
\hline 13 & $\mathrm{CW}_{4}$ & & $0,4,7$ \\
\hline 14 & D5 & 04,S5,S10 & $0 / 4,10$ \\
\hline $\begin{array}{l}15 \\
16\end{array}$ & $\begin{array}{l}15 \\
\text { v8 }\end{array}$ & & $\begin{array}{l}0 / 5,6 \\
0 / 6\end{array}$ \\
\hline 17 & x9 & & $0 / 7$ \\
\hline 18 & $x_{4}$ & & $0,7,10$ \\
\hline 19 & F8 & A6,D6,F5,H IO,JI,L3,N9, & 100 \\
\hline 20 & $05\}$ & $\mathrm{NIO}, 08, \mathrm{RI}, \mathrm{W} 4, \mathrm{~W} 7, \times 5, Y 4$ & $16 / 0$ \\
\hline $2 I$ & $\mathrm{z}_{5}$ & & IC/O \\
\hline 22 & T8 & & Id $/ 0$ \\
\hline 23 & c9 & & re'o \\
\hline 24 & NI & & $2 \mathrm{a} / \mathrm{o}$ \\
\hline 25 & R7 & DI ,M7,UIO,S9,06 & $3 a$ \\
\hline 26 & T2 & & 40 \\
\hline 27 & J2 & $12,13, \mathrm{H} 5$ & 50 \\
\hline 28 & E6 & T4,EIO,M5 & $6 \%$ \\
\hline 29 & B10 & MIO & $8 \%$ \\
\hline 30 & c8 & WIO,T7,P4,F10 & $9 \%$ \\
\hline $3 \mathbf{I}$ & Cw349 & $\mathrm{ZI}, \mathrm{TIO}, \mathrm{IIO}$ & $10 \%$ \\
\hline 32 & c6 & $\mathrm{B} 3, \mathrm{~B} 4, \mathrm{M} 2, \mathrm{~N} 7$ & $11 / 0$ \\
\hline 33 & $\mathbf{J} 3$ & & Ia Id \\
\hline 34 & K10 & A9 & Ic 5 \\
\hline 35 & cw630 & & Ia 7 \\
\hline 36 & CW22 & & Ia/I I \\
\hline 37 & B2 & HI,K I & Ic $2,3 \mathrm{a}$ \\
\hline 38 & F9 & T3 & $1 \mathrm{a} / 2 \mathrm{a}, \mathrm{II}$ \\
\hline 39 & $\mathrm{x} 2$ & $\mathrm{R} 6, \mathrm{v} 4$ & $1 \mathrm{a} / 4,10$ \\
\hline 40 & MI & H2 & $1 \mathrm{c} / 5,6,12$ \\
\hline $4 I$ & R2 & $\mathrm{Y} 3, \mathrm{R} 5, \mathrm{E} 7,17, \mathrm{~V} 7$ & $2 b / 1,5$ \\
\hline 42 & P8 & & $2 b /$ Iabde, 5 \\
\hline 43 & Q2 & F3 & $2 a / 4$ \\
\hline 44 & QI & s3 & $2 b / 5$ \\
\hline 45 & cw818 & $\mathbf{G} 8, \mathrm{~K} 7, \mathrm{RIO}$ & $2 b / 7$ \\
\hline 46 & Cw362 & & $2 a / 5,10,12$ \\
\hline 47 & FI & H3,CW106 & $3 a / 1$ \\
\hline 48 & CWII22 & & $3 a / 5$ \\
\hline 49 & $\mathbf{F} 2$ & s6,J5, VIO & $3 a / 1,8$ \\
\hline 50 & CW977 & Cw784 & $3 a / 1,8$ \\
\hline $5 \mathrm{I}$ & G9 & s2 & $3 a / 1 a b c d e, 3 b, 13$ \\
\hline 52 & K5 & $\mathbf{K 8 , K 9}$ & $3 a / 1,8,13$ \\
\hline 53 & F6 & & $3 \mathrm{~b} / 4,10$ \\
\hline 54 & PIO & L6,K4 & $3 a / 8$ \\
\hline 55 & C5 & & $3 a / 8,13$ \\
\hline 56 & к6 & & $4 / 5$ \\
\hline 57 & C2 & Q3,Q5 & $4 / 7$ \\
\hline 58 & A2 & $L 4,16$ & $4 / 10$ \\
\hline 59 & s4 & & $4 / 13$ \\
\hline
\end{tabular}


Table I (cont.)

\begin{tabular}{|c|c|c|c|}
\hline $\begin{array}{c}\text { Dienes } \\
\text { compatibility } \\
\text { group no. }\end{array}$ & Type strain & $\begin{array}{l}\text { Other mutually } \\
\text { compatible strains }\end{array}$ & $\begin{array}{l}\text { P/S type(s) } \\
\text { of strains in } \\
\text { group* }\end{array}$ \\
\hline 60 & $\mathrm{CW} 404 / \mathrm{A}$ & & $4 / 2,3,10,12$ \\
\hline $6 I$ & TI & & $5 / 1,3,12$ \\
\hline 62 & CWI & & $5 / 2,6$ \\
\hline 63 & YI & & $5 / 4$ \\
\hline 64 & G6 & G7 & $5 / 4,10$ \\
\hline 65 & T6 & м9 & $5 / 7$ \\
\hline 66 & CW565 & & $5 / 7,10,12$ \\
\hline 67 & $\mathbf{K} 2$ & SI & $6,4,5,9$ \\
\hline 68 & CW237 & & $6 / 4,10$ \\
\hline 69 & N4 & & $6 / 8$ \\
\hline 70 & D3 & D4 & $6 / 9$ \\
\hline 71 & CWII & & $6 / 2,3$ \\
\hline 72 & 03 & M4,o10,Cw677 & $7 / 1,5$ \\
\hline 73 & BI & $\mathrm{B} 5, \mathrm{~K} 3$ & $7 / 1,8,13$ \\
\hline 74 & u9 & & 81 \\
\hline 75 & P5 & CW927,D7,Gro & $8 / 1,3 b, 12,13$ \\
\hline 76 & 07 & $\mathrm{~N} 5, \mathrm{~V} 6, \mathrm{P} 7, \mathrm{~L} 7, \mathrm{R3}$ & $8 / 1,3 b, 5,12,13$ \\
\hline 77 & Cw516 & & $9 / 1$ \\
\hline 78 & P9 & $\mathrm{J} 4, \mathrm{CW} 335$ & $9 / 7,10$ \\
\hline 79 & u7 & & $9 / 11$ \\
\hline 80 & u8 & & $10 / 5$ \\
\hline 81 & Cw537 & CW337 & $10 / 8$ \\
\hline 82 & w6 & 18 & $10 / 5,6,9$ \\
\hline 83 & м6 & LIO & II $/ 10,12$ \\
\hline 84 & u6 & & $12 / 1,13$ \\
\hline 85 & $\mathrm{Cw} 384$ & CW792 & $13 / 4,10$ \\
\hline 86 & N8 & & $13 / 7,12$ \\
\hline 87 & 09 & & $13 / 4,7,10,12$ \\
\hline 88 & A3 & M3,A7 & $0 / 0$ \\
\hline 89 & c7 & & $0 / 0$ \\
\hline 90 & AI & & Atypical \\
\hline 91 & B7 & & Atypical \\
\hline 92 & c3 & & Atypical \\
\hline 93 & C4 & & Atypical \\
\hline 94 & E5 & & Atypical \\
\hline & 11 & & Atypical \\
\hline 96 & 14 & & Atypical \\
\hline 97 & R9 & & Atypical \\
\hline 98 & v9 & & Atypical \\
\hline
\end{tabular}

* Letters refer to subtypes of proticines (Senior, 1977). The absence of letters means strains are sensitive to all subtypes.

In general, all strains with the same $\mathrm{P} / \mathrm{S}$ type were compatible with one another and incompatible with any strain of a different $\mathrm{P} / \mathrm{S}$ type. There were only two exceptions to this behaviour: strains with apparently the same $\mathrm{P} / \mathrm{S}$ type $\left(\mathrm{Po} / \mathrm{S}_{4}\right)$ were of two distinct Dienes types; and strains $\mathrm{CW} 794(\mathrm{Po} / \mathrm{SI}), \mathrm{P} 6(\mathrm{Po} / \mathrm{SI}, 5) \mathrm{H} 6$ and $\mathrm{H} 7$ (both $\mathrm{Po} / \mathrm{S} 5)$ although of different $\mathrm{P} / \mathrm{S}$ types were compatible with one another. An explanation for this is suggested in the Discussion.

The definition of the Dienes line appeared to indicate to some extent the degree of relatedness of the strains. Strains of very different $S$ types gave well-defined Dienes lines, whereas strains such as $\mathrm{N}_{3}\left(\mathrm{Po} / \mathrm{SI}_{\mathrm{I}}, 8, \mathrm{I}_{3}\right)$ and $\mathrm{A5}\left(\mathrm{Po} / \mathrm{S}_{\mathrm{I}}, 8, \mathrm{II}, \mathrm{I} 3\right)$, which shared the same sensitivity to several proticines and only differed in their sensitivity to one proticine, gave less well-defined Dienes lines. It appeared, therefore, that most, if not all proticine-sensitivity characters were determinants of Dienes compatibility.

Proticine production (P type) as a determinant of the Dienes type. If the mutual inhibition 
Table 2. Dienes compatibility reactions between mutant strains and wild-type strains of the same P/S type

\begin{tabular}{|c|c|c|}
\hline \multicolumn{2}{|c|}{ Parent } & \multirow{2}{*}{$\begin{array}{l}\text { Mutant } \\
\text { P/S type* }\end{array}$} \\
\hline Strain & $\mathrm{P} / \mathrm{S}$ type & \\
\hline $\begin{array}{l}\text { FI } \\
\text { G6 } \\
\text { R2 } \\
\text { P4 }\end{array}$ & $\begin{array}{l}\mathrm{P}_{3 a} / \mathrm{S}_{1} \\
\mathrm{P}_{5} / \mathrm{S}_{4,10} \\
\mathrm{P}_{2 \mathrm{~b}} / \mathrm{SI}_{1}, 5 \\
\mathrm{P}_{9 /} \text { So }\end{array}$ & $\begin{array}{l}\mathrm{P}_{3} \mathrm{a} / \mathrm{So} \\
\mathrm{P}_{5} / \mathrm{S}_{4} \\
\mathrm{P} 2 \mathrm{~b} / \mathrm{S} 5 \\
\mathrm{Po} / \mathrm{So}\end{array}$ \\
\hline FIO & $\mathrm{P}_{9} / \mathrm{So}$ & $\mathrm{Po} / \mathrm{So}$ \\
\hline 110 & Pro/So & Po So \\
\hline
\end{tabular}

$\begin{array}{cc}\begin{array}{c}\text { Wild-type strain } \\ \text { with P/S type of } \\ \text { mutant }\end{array} & \begin{array}{c}\text { Reaction } \\ \text { with mutant }\end{array} \\ \text { R7 } & + \\ \text { YI } & + \\ \text { Q1 } & + \\ \text { A3 } & + \\ \text { C7 } & - \\ \text { A3 } & + \\ \text { C7 } & - \\ \text { A3 } & + \\ \text { C7 } & -\end{array}$

+ , Compatible; - , incompatible.

* No mutant was compatible with its parent.

between different strains of Proteus species observed in the Dienes test is solely determined by the $\mathrm{S}$ type of the strain, then those strains which produce different proticines but have a common $S$ type should be of the same Dienes type. The results of tests between such strains showed that this was not true. To eliminate the effect of the $S$ type character on the Dienes reaction, 5I proticine-producing strains that were insensitive to proticine (type $\mathrm{P} x / \mathrm{So}$ ) were tested for their Dienes compatibility. The results (Table 1 ) show that, in every case, strains that produced different proticines belonged to different and distinct Dienes types. Only strains that produced a common proticine were compatible with each other. Most strains producing subtypes of proticine I were of distinct compatibility groups. However, it was difficult to assign many of the strains of type Pra/So and PIb/So to either compatibility group because of uncertainty as to whether a Dienes line was present. Therefore, in addition to the $S$ type character, each $P$ type character also plays a role in determining Dienes compatibility.

Because both the $P$ type and $S$ type characters of a strain appeared to determine compatibility in the Dienes test, strains which are both proticinogenic and proticine-sensitive should be incompatible with all strains of a different $\mathrm{P} / \mathrm{S}$ type. Moreover, all strains that are both non-producers and insensitive to proticine (type Po/So strains) should be compatible with each other and belong to a unique compatibility group. The results (Table 1) show that these hypotheses were largely substantiated. Strains of the same P/S type were compatible with one another but were incompatible with any other strain of a different $\mathrm{P} / \mathrm{S}$ type. Strain $\mathbf{P} 8$ $(\mathrm{P} 2 \mathrm{~b} / \mathrm{S} \mathrm{I}$ abde,5) has given on different occasions both reactions of compatibility and reactions of incompatibility with the group of very similar strains of P/S type P2b/S Iabcdef,5. Strain P5 (P8/SI,3b,I 2, I 3) reacted similarly with the closely related strain $07(\mathrm{P} 8 / \mathrm{S} I, 3 \mathrm{~b}, 5$, I 2,I3). There appeared to be at least two compatibility groups for strains of the apparent $\mathrm{P} / \mathrm{S}$ type $\mathrm{P}_{3} \mathrm{a} / \mathrm{S} \mathrm{S}, 8$. Repeated examination of these incompatible groups of strains has failed to show any differences between their $\mathrm{P} / \mathrm{S}$ types. There may be a third compatibility group in this P/S type; a faint Dienes line was occasionally seen between strains CW784 and CW977, suggesting that these strains may be incompatible. Only four of the eight strains of the type Po/So swarmed and all except strain $\mathrm{c} 7$ belonged to a single, unique compatibility group. The remaining strains were those producing hitherto undefined 'atypical' proticines. Among these were nine swarming strains, sensitive to a number of different proticines. Each strain belonged to a unique compatibility group.

Dienes reactions of proticine-resistant mutant strains. In a few of the original isolates that had been stored for 2 years, variant strains were found which were incompatible in Dienes tests with the original parent strain. $\mathrm{P} / \mathrm{S}$ typing showed that either proticine-sensitivity 


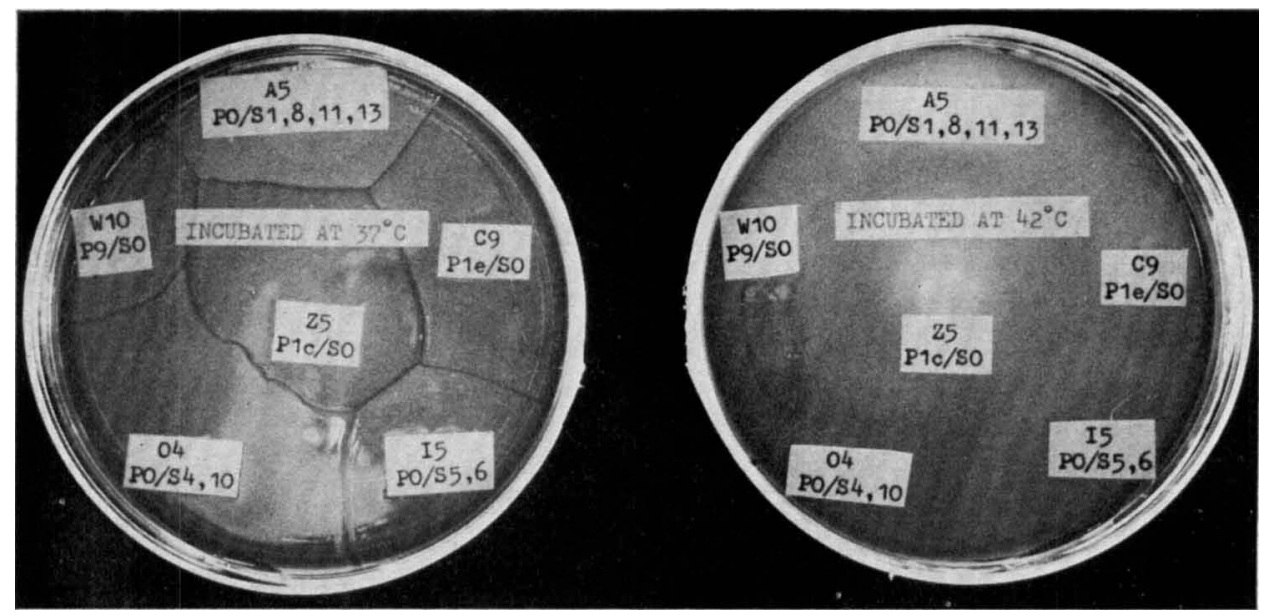

Fig. 2. At $37^{\circ} \mathrm{C}$, strains of Proteus species of different $\mathrm{P} / \mathrm{S}$ types show Dienes incompatibility, but at $42{ }^{\circ} \mathrm{C}$ no Dienes lines are formed and the strains appear to be compatible with each other.

characters or the ability to produce proticine had been lost. Proticine-resistant mutants were also isolated from several proticine-sensitive strains capable of swarming on blood agar. Some of these mutants were unable to swarm. However, among the mutants capable of swarming, some were compatible and some incompatible with the parent strain. From a knowledge of the $\mathrm{P} / \mathrm{S}$ types of the members of the latter group of mutants and the variant strains, it was predicted that these strains should be compatible with wild-type strains of the same $\mathrm{P} / \mathrm{S}$ type. In most instances, wild-type strains of the required $\mathrm{P} / \mathrm{S}$ type were not available, but in the few cases where they were, the predictions were correct (Table 2).

\section{Effect of incubation at $42{ }^{\circ} \mathrm{C}$ on proticine production, proticine sensitivity and Dienes typing}

Examination of plates incubated at 37 and $42{ }^{\circ} \mathrm{C}$ showed that all the standard proticines were produced at $37{ }^{\circ} \mathrm{C}$ but not at $42{ }^{\circ} \mathrm{C}$. Failure of proticine production at $42{ }^{\circ} \mathrm{C}$ was not due to the loss of the genetic determinant for such production since producing strains grown at $42{ }^{\circ} \mathrm{C}$, inoculated on to PNPG blood agar plates and subsequently incubated at $37^{\circ} \mathrm{C}$, again produced proticines. Indicator strains on plates incubated at 37 and $42{ }^{\circ} \mathrm{C}$ showed the same patterns of inhibition by the standard proticines produced at $37^{\circ} \mathrm{C}$ indicating that incubation at $42{ }^{\circ} \mathrm{C}$ affected neither the sensitivity of the indicator strains nor the proticine itself.

If proticine production is required for the formation of a Dienes line then incubation at $42{ }^{\circ} \mathrm{C}$ should prevent the formation of this line and strains of the type Px/So and Py/So should give the reaction of compatibility at this temperature. Most strains failed to swarm at $42{ }^{\circ} \mathrm{C}$ on $\mathrm{I} \cdot 5 \%(\mathrm{w} / \mathrm{v})$ blood agar. However, those strains of different $\mathrm{P} / \mathrm{S}$ type that were able to swarm at $42{ }^{\circ} \mathrm{C}$ formed Dienes lines at $37^{\circ} \mathrm{C}$ but not at $42{ }^{\circ} \mathrm{C}$ (Fig. 2). Non-producing strains of different proticine sensitivity also gave reactions of compatibility at $42{ }^{\circ} \mathrm{C}$. To obtain swarming of the remaining strains at $42{ }^{\circ} \mathrm{C}$, the agar concentration had to be reduced to $0.5 \%(\mathrm{w} / \mathrm{v})$. Many strains of different $\mathrm{P} / \mathrm{S}$ types were tested on this medium at $42{ }^{\circ} \mathrm{C}$ and all gave reactions of compatibility with one another, whereas they were incompatible on control plates incubated at $37^{\circ} \mathrm{C}$. 


\section{DISCUSSION}

The Dienes phenomenon cannot be explained simply on the basis of sensitive cells being killed by proticine because different non-producing strains may give Dienes lines and proticine-insensitive strains of different $P$ type are incompatible. However, both the proticine production ( $P$ type) and proticine sensitivity ( $S$ type) characters are implicated as determinants of compatibility. With very few exceptions, strains of the same P/S type were compatible with one another, whereas strains of different $\mathrm{P} / \mathrm{S}$ types were incompatible. In those few instances where strains of the same $\mathrm{P} / \mathrm{S}$ type were incompatible with one another, one of the strains was probably producing a slightly different proticine (say a new subtype) or possessed a sensitivity to an, as yet, undefined proticine. There are a number of strains which produce such 'atypical' proticines (Senior, 1977). It seems highly improbable that the observed correlation between $\mathrm{P} / \mathrm{S}$ type and Dienes compatibility was a fortuitous character of locally isolated strains, because each strain was a single isolate from unrelated individuals and the Cradock-Watson strains isolated in a number of Public Health Service laboratories also behaved as predicted from their $\mathbf{P} / \mathbf{S}$ types. Moreover, the correlation was not restricted to swarming strains of $P$. mirabilis; each of three strains of $P$. vulgaris showed compatibility with the strains of $P$. mirabilis that had an identical $\mathrm{P} / \mathrm{S}$ type.

The role of the $\mathbf{P}$ type and $\mathrm{S}$ type characters in determining compatibility is obscure. Incompatibility between two proticine-insensitive strains that produced different proticines suggested the involvement of the $P$ type as a determinant of strain compatibility. Moreover, the incompatibility between strains producing the different subtypes of proticine I substantiated the claim (Senior, 1977) that these were related but distinct proticines. If the plasmid for proticine production rather than its product (proticine) is the determinant of compatibility, incompatibility or exclusion between proticine plasmids might lead to the formation of a Dienes line between strains of different $P$ types. Furthermore, this reaction would be independent of restrictions demanding accompanying sensitivity to a particular proticine. If this were correct, strains of the type Px/So should be compatible with strains of the type $\mathrm{Po} / \mathrm{So}$, since there are neither restraints of proticine sensitivity, nor of plasmid. Such compatibility, however, was not observed with strains believed to be of the Po/So type.

Evidence for the importance of proticine production in the formation of the Dienes line was provided by the experiment in which the formation of Dienes lines was prevented and normally incompatible strains gave reactions of compatibility at an incubation temperature of $42{ }^{\circ} \mathrm{C}$. At this temperature no active proticine was produced.

What is the role of proticine in the formation of the Dienes line? In those instances where one swarming strain is sensitive to proticine produced by the other swarmer, killing can take place and the area of inhibited growth will appear as a narrow Dienes line because the diffusion rate in agar for all the standard proticines is slow (unpublished results). The action of certain proticines on sensitive cells, like that of some colicins, might be on the cytoplasmic membrane, leading to the swelling of the sensitive cell and the formation of the large bodies observed by Dienes (1946). Attempts to produce artificial Dienes lines by swarming proticine-sensitive strains towards reservoirs of proticine from either mitomycin C-induced cultures of producer strains or from proticine produced by prior growth of non-swarming producer strains on blood agar, have been unsuccessful, possibly because contact between swarming cells is necessary. It is unlikely that the only role of proticine is its lethal action on sensitive cells because, if plasmid incompatibility is excluded, there is no explanation for the incompatibility that exists between strains which produce different proticines and which are insensitive to proticine. In these instances each proticine must have at least two specific roles; one is to inhibit the growth of strains sensitive to its proticine and the other is to elicit either a negative chemotactic response or a temporary inhibition of growth in all strains not producing that particular proticine. The definition of the Dienes line would thus be influenced by the interplay of proticine eliciting a lethal or growth-inhibitory action, negative 


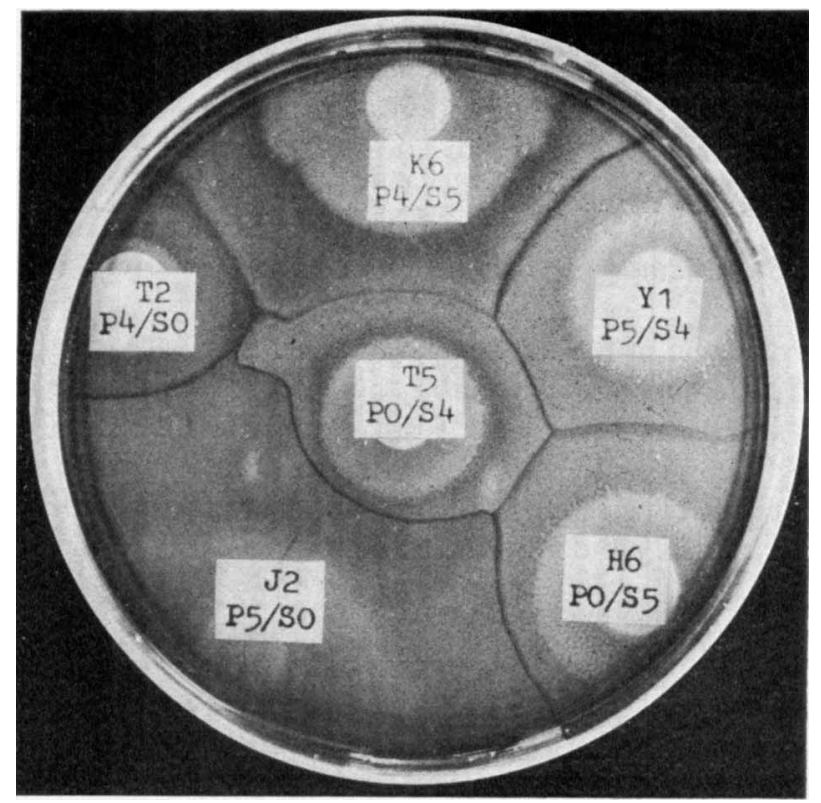

Fig. 3. The different appearance of Dienes lines which form between incompatible strains may be the outcome of the interplay of several inhibitory factors in addition to proticine.

chemotaxis and possibly even genetic incompatibility. This would account for the varied appearances of Dienes lines in tests between different strains (Fig. 3).

The role of the $\mathrm{S}$ type character in determining compatibility is even harder to explain. Its involvement was suggested when strains of different proticine sensitivity, which failed to produce a standard type of proticine, were found to be incompatible with one another. These types of strains cannot strictly be called 'non-producers' for they may produce proticines for which there is no indicator or possess genetic elements for proticine production which are in a state of repression. However, it is unlikely that these explanations are true for all such strains.

Proticine sensitivity is probably analogous to colicin sensitivity and determined by the presence of specific receptors situated on the cell surface. Some colicin receptors are multifunctional and as well as adsorbing specific colicins also adsorb certain phages, other colicins, iron and vitamins (Fredericq, I949 $a, b$; Fredericq \& Smarda, I970; Jasper, Whitney \& Silver, I972; Di Masi et al., I973; Guterman \& Dann, I973; Sabet \& Schnaitman, I973). Possibly proticine receptors are similarly multifunctional. When the proticine receptors present on a swarming strain adsorb the corresponding proticine produced by another swarming strain, growth will be inhibited and a Dienes line formed. However, in all other instances the receptor may function in one of its other roles. Any difference between the $S$ type of opposing swarms would be rapidly detected and any resulting negative chemotactic response arising from specific chemical adsorption by the distinguishing receptor would result in the formation of a Dienes line. The failure of formation of Dienes lines at $42{ }^{\circ} \mathrm{C}$ between non-producing strains of different $S$ type while these strains retain sensitivity to proticine could be due to heat-induced changes at the receptor site permitting proticine to act but inhibiting either adsorption and/or the negative chemotactic response to other chemicals.

The behaviour of certain of the mutants selected for proticine resistance is thought to be similar to that of these colicin-tolerant strains. These proticine-resistant mutants have an $S$ type different from the parent strain and yet they show Dienes compatibility with the parent 
strain and incompatibility with wild-type strains of the same $P / S$ type as the mutant. Thus in these mutants the receptor appears to be maintained in some way but the strain is tolerant to the proticine, suggesting that the proticine receptor does not necessarily have to be in an 'active' state (i.e. one permitting lethal action of proticine) to play a role in determining compatibility. The seemingly erroneous reaction of compatibility between such strains as P6 ( $\left.\mathrm{Po} / \mathrm{SI}_{1}, 5\right)$ and $\mathrm{H} 6\left(\mathrm{Po} / \mathrm{S}_{5}\right)$ could therefore be explained on the basis that strain $\mathrm{H} 6$ possesses the proticine I receptor but is tolerant to the action of proticine $I$. This is feasible because sensitivity to proticine 5 is often associated with sensitivity to proticine I (Senior, 1977).

The overall picture is one of the interaction between the $P$ type and $S$ type characters of swarming strains. If differences are detectable the outcome will be the inhibition of growth and the formation of a Dienes line. Alternatively, if no differences are detectable, the opposing swarmer is recognized as 'self' and the strains will be compatible with each other. It is hoped that further genetic experiments will add support to the evidence presented that both $P$ type and $S$ type characters are determinants of compatibility in the Dienes test.

\section{REFERENCES}

Cunliffe, A. C. \& KrikLeR, M. S. (1953). A cultural test for the presumptive serological identity of strains of Proteus vulgaris. Abstracts. International Congress for Microbiology, Roma 6, 861-862.

DE Louvols, J. (1969). Serotyping and the Dienes reaction on Proteus mirabilis from hospital infections. Journal of Clinical Pathology 22, 263-268.

Dienes, L. (1946). Reproductive processes in Proteus cultures. Proceedings of the Society for Experimental Biology and Medicine 63, 265-270.

Di Masi, D. R., White, J. C., Schnaitman, C. A. \& BradbeER, C. (1973). Transport of vitamin B 12 in Escherichia coli: common receptor sites for vita$\mathrm{min} B 12$ and the E colicins on the outer membrane of the cell envelope. Journal of Bacteriology 115 , 506-513.

FredericQ, P. (1949a). Sur la résistance croisée entre colicine $\mathrm{E}$ et bactériophage II. Comptes rendus des séances de la Société de biologie 143 , IOI I-IOI 3.

FrederICQ, P. (1949b). Sur la résistance croisée entre colicine $\mathrm{K}$ et bactériophage III. Comptes rendus des séances de la Société de biologie 143 , 1014-1017.

FredericQ, P. \& Smarda, J. (1970). Complexité du facteur colicinogène B. Annales de l'Institute Pasteur 118, 767-774.

George, R. H. (1974). Comparison of different media for bacteriocine typing of Proteus mirabilis. Journal of Clinical Pathology 28, 25-28.
Guterman, S. K. \& DanN, L. (1973). Excretion of enterochelin by $e x b A$ and $e x b B$ mutants of Escherichia coli. Journal of Bacteriology I14, $1225-1230$.

JASPER, P., Whitney, E. \& Silver, S. (1972). Genetic locus determining resistance to phage $\mathrm{BF}_{23}$ and colicins $\mathrm{E}_{1}, \mathrm{E}_{2}$ and $\mathrm{E}_{3}$ in Escherichia coli. Genetical Research 19, 305-312.

KOPP, R., MülleR, J. \& LEMME, R. (I966). Inhibition of swarming of Proteus by sodium tetradecyl sulfate, $\beta$-phenethyl alcohol, and $p$-nitrophenylglycerol. Applied Microbiology 14, 873-878.

Sabet, S. F. \& Schnaitman, C. A. (1973). Purification and properties of the colicin $E_{3}$ receptor of Escherichia coli. Journal of Biological Chemistry 248, I 797-I 806.

SENIOR, B. W. (1977). Typing of Proteus strains by proticine production and sensitivity. Journal of Medical Microbiology ro, 7-17.

SkIRrow, M. B. (1969). The Dienes (Mutual Inhibition) test in the investigation of Proteus infections. Journal of Medical Microbiology 4, $471-477$.

SOUREK, J. (1968). On some findings concerning Dienes's phenomenon in swarming Proteus strains. Zentralblatt für Bakteriologie, Parasitenkunde, Infektionskrankheiten und Hygiene (Abteilung I) Originale 208, 419-427.

Story, P. (1954). Proteus infections in hospitals. Journal of Pathology and Bacteriology 68, 55-62. 